\title{
EFEKTIVITAS PELAKSANAAN PROGRAM KAMPUNG IKLIM (PROKLIM) DI DESA POLEONRO KECAMATAN LAMURU KABUPATEN BONE PROVINSI SULAWESI SELATAN
}

\author{
Sudarwanto ${ }^{1}$, Amir Tjoneng ${ }^{2}$, Suriyanti \\ ${ }^{1}$ Alumni Pasca Sarjana Agroteknologi Universitas Muslim Makassar \\ ${ }^{2}$ Dosen Pasca Sarjana Agroteknologi Universitas Muslim Makassar \\ Email : amir.tjoneng@umi.ac.id suriyanti.suriyanti@umi.ac.id
}

\begin{abstract}
This study aims 1). Analyzing the effectiveness of the implementation of the Village Climate Program activities in Poleonro Village; 2). Analyzing the level of community participation in the implementation of the Climate Village Program in Poleonro Village; 3). Analyzing the relationship between the socio-economic factors of the community on the level of community participation in the Climate Village Program (PROKLIM) in Poleonro Village.

The research was conducted in Poleonro Village, Lamuru District, Bone Regency, South Sulawesi Province. Field data collection, data processing, and analysis, as well as thesis preparation, took place from February to August 2020. The method used in this research was a descriptive method with interviews, questionnaires, observation, and documentation. Data analysis used a descriptive qualitative analysis and multiple linear regression.

The results showed that the implementation of the Climate Village Program (PROKLIM) in Poleonro Village was classified as effective. This result according to the activity component of the Climate Village Program (PROKLIM) which had carried out climate change adaptation activities were $70.12 \%$, climate change mitigation activities were $60.06 \%$, and group activities of community and support for sustainability were 72.77\%. The level of community participation in the implementation of the Climate Village Program (PROKLIM) activities in Poleonro Village for climate change adaptation, climate change mitigation, group activities of community and support for the sustainability of the level of participation was high. The level of education and counseling has a positive relationship with PROKLIM activities, while the variables age and income level have a negative relationship with the level of participation.
\end{abstract}

Keywords : ProKlim; Community Participation; Effectiveness

\section{PENDAHULUAN}

Perubahan iklim adalah berubahnya

iklim yang diakibatkan langsung atau tidak langsung oleh aktivitas manusia. Hal ini dapat diamati dengan adanya perubahan pola, intensitas atau pergeseran parameter utama iklim seperti curah hujan, suhu, kelembaban, angin, tutupan awan dan penguapan. Perubahan iklim berdampak pada ekosistem dan manusia di seluruh bagian benua dan samudera di dunia.
Perubahan iklim dapat menimbulkan risiko besar bagi kesehatan manusia, keamanan pangan, dan pembangunan ekonomi. Mengingat dampak dari perubahan iklim ini sangat kompleks yang mencakup banyak sektor, maka penyelesaian masalah yang dihadapi juga harus dilakukan secara terpadu dari berbagai sektor sehingga adaptasi dan mitigasi perubahan iklim dapat disinergikan dalam sistem pembangunan nasional. Perubahan iklim telah terjadi dan 
dampaknya sudah dirasakan oleh semua makhluk hidup di belahan bumi ini, maka diperlukan upaya untuk mengendalikan dampak dari perubahan iklim, baik dengan cara adapatasi, mitigasi atau kombinasi keduanya

Salah satustrategi KementerianLingkungan Hidup dan Kehutanan (KLHK) dalam upaya pengendalian perubahan iklim adalah dengan mendorong kerjasama multi-pihak untuk memperkuat kapasitas adaptasi dan mitigasi perubahan iklim di tingkat tapak berbasis komunitas melalui pelaksanaan Program Kampung Iklim (ProKlim). Dalam Pasal 70, UU Republik Indonesia Nomor 32 Tahun 2009 tentang Perlindungan dan Pengelolaan Lingkungan Hidup, ditegaskan bahwa masyarakat memiliki hak dan kesempatan yang sama danseluas-luasnya untuk berperan aktif dalam perlindungan dan pengelolaan lingkungan hidup. Masyarakat dapat berperan aktifdengan cara meningkatkan kepedulian dalam perlindungan dan pengelolaan lingkungan hidup, meningkatkan kemandirian, keberdayaan masyarakat, dan kemitraan, menumbuh kembangkan kemampuan dan kepeloporan masyarakat, menumbuh kembangkan ketanggap segeraan masyarakat untuk melakukan pengawasan sosial, sertamengembangkan dan menjaga budaya dankearifan lokal dalam rangka pelestarian fungsi lingkungan hidup untuk menjaga kelangsungan kehidupan di bumi (KLHK, 2017).
Melihat pentingnya peranan Program Kampung Iklim (ProKlim) yang merupakan aksi nyata ditingkat tapak dalam pengendalian perubahan iklim sehingga perlu dilakukan penelitian tentang “Efektivitas Pelaksanaan Program Kampung Iklim (ProKlim) di Desa Poleonro Kecamatan Lamuru Kabupaten

\section{Bone Provinsi Sulawesi Selatan”.}

Tujuan dari penelitian ini adalah :

1. Menganalisis efektivitas pelaksanaan kegiatan Program Kampung Iklim di Desa Poleonro

2. Menganalisis tingkat partisipasi masyarakat mengenai pelaksanaan Program Kampung iklim di Desa Poleonro

3. Menganalisis hubungan antara faktor sosial ekonomi masyarakat terhadap tingkat partisipasi masyarakat dalam pelaksanaan Program Kampung IKlim di Desa Poleonro

\section{METODE PENELITIAN}

Penelitian dilaksanakan di Desa Poleonro, Kecamatan Lamuru, Kabupaten Bone, Provinsi Sulawesi Selatan. Pengumpulan data lapangan, pengolahan dan analisis data dilakasanakan pada bulan Februari s.d Agustus 2020. Metode yang digunakan dalam penelitian ini adalah metode deskriptif dengan teknik wawancara, kuesioner, observasi dan dokumentasi.analisa data yang digunakan yaitu analisa deskriptif kualitatif dan regresi linear berganda. 


\section{HASIL DAN PEMBAHASAN}

Program Kampung Iklim atau yang di sebut ProKlim adalah program pemerintah dalam rangka mendorong masyarakat untuk melakukan peningkatan kapasitas adaptasi masyarakat desa/ kelurahan terhadap dampak perubahan iklim dan penurunan emisi gas rumah kaca serta memberikan penghargaan terhadap upaya-upaya adaptasi dan mitigasi perubahan iklim yang telah dilaksanakan di tingkat lokal sesuai dengan kondisi wilayah. Dalam penelitian ini penulis melakukan pengkajian tentang pelaksanaan Program Kampung Iklim (ProKlim) yang dilaksanakan oleh masyarakat. Adapun hasil penelitian sebagai berikut:

\section{Efektivitas pelaksanaan Program Kampung Iklim;}

1.1 Efektivitas Kegiatan Adaptasi Perubahan Iklim

Hasil penelitian menunjukan bahwa pelaksanaan kegiatan adaptasi perubahan iklim di Desa Poleonro termasuk dalam kategori cukup efektif dengan nilai sebesar 70,12\%. Berbagai upaya kegiatan yang telah dilakukan masyarakat untuk bisa menyesuaikan diri dari perubahan iklim, masyarakat Desa Poleonro secara umum sudah melaksanakan aksi adaptasiperubahan iklim.

Adapun kegiatan adaptasi perubahan iklim yang dilakukan adalah melakukan pemanenan air hujan, membuat peresapan air, melakukan perlindungan mata air, melakukan penghematan penggunaan air, memelihara sarana dan prasarana pengendali banjir, membuat rancnag bangun adaptif, membuat terasering, melakukan system pola tanam, melakukan system irgasi, melakukan pertanian terpadu,melakukan penganekaragaman tanaman pangan, melakukan pemanfaatan lahan pekarangan, melakukan pengendalian vektor penyakit, melakukan salitasi dan air bersih, dan melakukan Pola Hidup Bersih dan Seha (PHBS).

1.2. Efektivitas Kegiatan mitigasi Perubahan Iklim

Berdasarkan hasil penelitian menunjukkan bahwa pelaksanaan kegiatan mitigasi perubahan iklim di Desa Poleonro termasuk dalam kategori cukup efektif dengan nilai $66,06 \%$. Berbagai upaya kegiatan yang telah dilakukan masyarakat untuk biasa mengurangi dampak perubahan iklim, masyarakat Desa Poleonro secara umum sudah melaksanakan aksi mitigasi perubahan iklim

Adapun kegiatan mitigasi perubahan iklim yang dilakukan adalah melakukan Pengelolaan limbah padat, melakukan Pengolahan limbah dan pemanfaatan limbah cair, melakukan Penggunaan energi baru terbarukan dan konservasi energi, melakukan Pengolahan budidaya pertanian, melakukan 
Peningkatan tutupan vegetasi, dan melakukan Tabel 1. Data partisipasi masyarakat pada pencegahan dan menanggulang kebakaran hutan dan lahan.

1.3. Efektivitas kegiatan kelompok masyarakat dan dukungan keberlanjutan

Hasil penelitian menunjukan bahwa pelaksanaan kelompok masyarakat dan dukungan keberlanjutan di Desa Poleonro termasuk dalam kategori cukup efektif dengan nilai sebesar $72,77 \%$.

Adapun kegiatan kelompok masyarakat dan dukungan keberlanjutanyang dilakukan meliputi : Masyarakat terlibat dalam Kelompok Masyarakat, melakukan Dukungan kebijakan, melakukan Tingkat keswadayaan masyarakat, aktif dalam peningkatan kapasitas masyarakat, mendapat dukungan eksternal, memanfaatkan lingkungan, melakukan Manfaat ekonomi, melakukan Manfaat sosial dan Masyarakat melakukan Manfaat sosial, ekonomi, lingkungan dan pengurangan risiko bencana terkait iklim.

\section{Tingkat Partisipasi Masyarakat Dalam Pelaksanaan ProKlim}

2.1 Tingkat Partisipasi Masyarakat dalam kegiatan Adaptasi Perubahan Ikim

Berdasarkan hasil penelitian menunjukan

\begin{tabular}{ccccc}
\hline $\begin{array}{c}\text { Kategori } \\
\text { Partisipasi }\end{array}$ & Skala & Frek & Skor & \% \\
\hline Sangat Setuju & 5 & 281 & 1405 & 28,03 \\
Setuju & 4 & 745 & 2980 & 59,56 \\
Netral & 3 & 187 & 561 & 11,24 \\
Tidak Setuju & 2 & 25 & 50 & 0,99 \\
Sangat tdk Setuju & 1 & 7 & 7 & 0,18 \\
Total & & & 5003 & 100 \\
\hline
\end{tabular}

Tabel 2. Kategori interval partisipasi masyarakat pada kegiatan adaptasi perubahan iklim

\begin{tabular}{cc}
\hline Kategori partisipasi & Interval \\
\hline Sangat tinggi & $5229-6225$ \\
Tinggi & $4233-5229$ \\
Sedang & $3237-4233$ \\
Rendah & $2241-3237$ \\
Sangat Rendah & $1245-2241$ \\
\hline
\end{tabular}

Dari tabel diatasdiketahui total skor yang diperoleh adalah sebesar 5003 sehingga dapat disimpulkan bahwa tingkat partisipasi masyarakat Desa Poleonro pada kegiatan adaptasi perubahan iklim dapat dikatakan Tinggi karena berada pada tingkat interval 4233 -5229 .

2.2 Tingkat Partisipasi Masyarakat dalam kegiatan Adaptasi Perubahan Ikim

Berdasarkan hasil penelitian menunjukan bahwa tingkat partsisipasi masyarakat dalam kegiatan mitgasi dapat dilihat pada tabel berikut: bahwa tingkat partsisipasi masyarakat dapat dilihat pada tabel berikut: 
Tabel 3. Data partisipasi masyarakat pada kegiatan mitigasi perubahan iklim

\begin{tabular}{ccccc}
\hline Kategori & & & & \\
Partisipasi & Skala & Frek & Skor & \% \\
\hline Sangat Setuju & 5 & 92 & 460 & 23,38 \\
Setuju & 4 & 304 & 1216 & 51,81 \\
Netral & 3 & 89 & 267 & 13,57 \\
Tidak Setuju & 2 & 11 & 22 & 1,19 \\
Sangat tdk Setuju & 1 & 2 & 2 & 0,05 \\
Total & & & 1967 & 100 \\
\hline
\end{tabular}

Tabel 4. Kategori interval partisipasi masyarakat pada kegiatan mitigasi perubahan iklim

\begin{tabular}{cc}
\hline Kategori partisipasi & Interval \\
\hline Sangat tinggi & $2092-2490$ \\
Tinggi & $1694-2092$ \\
Sedang & $1296-1694$ \\
Rendah & $898-1296$ \\
Sangat Rendah & $500-898$ \\
\hline
\end{tabular}

Dari tabel diatasdiketahui total skor yang diperoleh adalah sebesar 1967 sehingga dapat disimpulkan bahwa tingkat partisipasi masyarakat Desa Poleonro pada kegiatan mitigasi perubahan iklim dapat dikatakan Tinggi karena berada pada tingkat interval 1694 -2092 .

2.3 Tingkat Partisipasi Masyarakat dalam kegiatan kelompok masyarakat dan dukungan keberlanjutan.

Berdasarkan hasil penelitian menunjukan bahwa tingkat partsisipasi masyarakat dalam kegiatan kelompok masyarakat dan dukungan keberlanjutandapat dilihat pada tabel berikut:
Tabel 5. Data partisipasi masyarakat pada kegiatan kelompok masyarakat dan dukungan keberlanjutan

\begin{tabular}{ccccc}
\hline $\begin{array}{c}\text { Kategori } \\
\text { Partisipasi }\end{array}$ & Skala & Frek & Skor & \% \\
\hline Sangat Setuju & 5 & 199 & 995 & 19,75 \\
Setuju & 4 & 485 & 1940 & 58,01 \\
Netral & 3 & 122 & 366 & 10,94 \\
Tidak Setuju & 2 & 19 & 38 & 1,13 \\
Sangat tdk Setuju & 1 & 5 & 5 & 0,14 \\
Total & & & 3344 & 100 \\
\hline
\end{tabular}

Tabel 6. Kategori interval partisipasi masyarakat pada kelompok masyarakat dan dukungan keberlanjutan.

\begin{tabular}{cc}
\hline Kategori partisipasi & Interval \\
\hline Sangat tinggi & $3486-4150$ \\
Tinggi & $2822-3486$ \\
Sedang & $2158-2822$ \\
Rendah & $1494-2158$ \\
Sangat Rendah & $830-1494$ \\
\hline
\end{tabular}

Dari tabel diatas diketahui total skor yang diperoleh adalah sebesar 3344 sehingga dapat disimpulkan bahwa tingkat partisipasi masyarakat Desa Poleonro pada kegiatan kelompok masyarakat dan dukungan keberlanjutan dapat dikatakan Tinggi karena berada pada tingkat interval $2822-3486$.

\section{Analisis Hubungan Sosial Ekonomi Masyarakat Terhadap Tingkat Partisipasi Masyarakat Pada Kegiatan Proklim.}

Analisis hubungan sosial ekonomi masyarakat terhadap tingkat partisipasi masyarakat pada kegiatan program Kampung iklim diketahui berdasarkan analisa regresi linear berganda untuk kegiatan adaptasi perubahan iklim, mitigasi perubahan iklim, 
kelompok masyarakat dan dukungan keberlanjutan.

3.1 Analisis Hubungan Sosial Ekonomi Masyarakat Terhadap Tingkat Partisipasi Masyarakat Pada Kegiatan Adaptasi Perubahan Iklim.

Dari analisis regresi linear berganda tingkat partisipasi masyarakat dalam kegiatan adaptasi perubahan ikilm diperoleh model

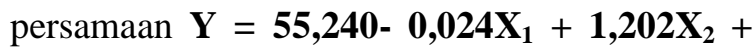

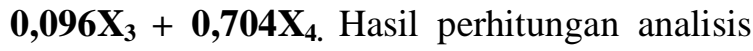
korelasi diketahui bahwa korelasi antara variabel $\mathrm{X}_{1}$ sampai dengan $\mathrm{X}_{4}$ dengan variabel Y adalah sebesar 55,240, hal ini menjelaskan bahwa tingkat partisipasi masyarakat dalam kegiatan adaptasi perubahan iklim dipengaruhi oleh keempat karakteristik responden.

Hasil analisis regresi memperlihatkan bahwa hubungan positif antara tingkat partisipasi masyarakat dalam kegiatan adaptasi perubahan iklim (Y) terjadi pada faktor tingkat pendidikan (X2) dan Penyuluhan (X4) sedangan umur (X1), pendapatan (X2) dan memiliki hubungan negative.

Hasil analisis regresi untuk faktor pendidikan (X2) dan faktor penyuluhan (X4) dengan tingkat partisipasi dalam kegiatan adaptasi perubahan iklim adalah positif $(b=$ 1,202) dan $(b=0,704)$, hal ini berarti semakin bertambah tinggi tingkat pendidikan dan keikutan dalam penyuluhan, maka tingkat partisipasi masyarakat dalam kegiatan adaptasi perubahan iklim akan semakin meningkat. Hal ini dikarenakan tinggi rendahnya pendidikan seseorang berpengaruh dalam pelaksanaan suatu kegiatan. Mereka yang berpendidikan tinggi relatif lebih cepat dalam melakukan anjuran pemerintah/ penyuluhan. Tingkat pendidikan yang rendah pada umumnya kurang menyenangi inovasi sehingga sikap mental untuk menambah pengetahuan khususnya ilmu pertanian kurang. Pendidikan dianggap dapat mempengaruhi sikap seseorang dalam memutuskan sesuatu yangterbaik bagi dirinya untuk ikut berpartisipasiatau tidak dalam program-programpembangunan(Jaya et a,l, 2016).

Sedangkan hasil analisis untuk fakor umur (X1) dan pendapatan (X3) memiliki hubungan negatif. Untuk umur (X1) dengan tingkat partisipasi dalam kegiatan adaptasi perubahan iklim adalah negatif $(b=-0,094)$ dan $(b=0,96)$. Hasil penelitian ini mengindikasikan bahwa semakin tinggi umur seseorang maka tingkat partisipasi mereka dalam kegiatan adaptasi perubahan iklim akan semakin menurun. Seseorang dalam usia produktif 3050 tahun akan mempunyai tanggung jawab yang lebih besar dalam menghidupi dirinya dan keluarganya dibandingkan mereka yang berusia di bawah 30 tahun maupun di atas 50 tahun. Pada kisaran umur tersebut, petani mencapai kematangan dalam bertani karena sudah 
ditekuni sejak usia muda, dan termasuk umur produktif. Umur tenaga kerja cukup menentukan keberhasilan dalam melakukan suatu pekerjaan, baik sifatnya fisik maupun non fisik. Pada umumnya, tenaga kerja yang berumur tua mempunyai tenaga fisik yang lemah dan terbatas, sebaliknya tenaga kerja yang berumur muda mempunyai kemampuan fisik yang kuat (Amron, 2009).

Hasil perhitungan koefisien korelasi untuk tingkat pendapatan (X3) dengan tingkat partisipasi memperlihatkan hasil negatif $(b=-$ 0,096). Hal ini memperlihatkan bahwa, semakin rendah pendapatan seseorang maka tingkat partisipasi mereka akan semakin meningkat, sebaliknya apabila pendapatan mereka meningkat maka partisipasi mereka dalam kegiatan adaptasi perubahan iklim akan menurun. Hasil penelitian ini memperlihatkan bahwa mayoritas masyarakat berpartisipasi dalam kegiatan adaptasi perubahan ikilm, hal ini dikarenakan kegiatan adaptasi ini merupakan kegiatan sehari-hari yang merupakan pekerjaan mereka sebagai petani. Dengan semakin rendah tingkat pendapatan masyarakat akat semakin berpartisipasi dalam kegiatan adaptasi karena dapat memberikan atau meningkatkan pendapatan keluarga mereka.

3.2 Analisis Hubungan Sosial Ekonomi Masyarakat Terhadap Tingkat Partisipasi Masyarakat Pada Kegiatan mitgasi Perubahan Iklim
Analisis regresi linear berganda untuk tingkat partisipasi masyarakat dalam kegiatan mitigasi perubahan ikilm diperoleh model persamaan sebagai berikut : $\quad \mathrm{Y}=21,339+$ $0,001 X_{1}+0,473 X_{2}+0,228 X_{3}+0,177 X_{4}$. Hasil perhitungan analisis korelasi diketahui bahwa korelasi antara variabel $X_{1}$ sampai dengan $X_{4}$ dengan variabel Y adalah sebesar 21,339, hal ini menjelaskan bahwa tingkat partisipasi masyarakat dalam kegiatan mitigasi perubahan iklim dipengaruhi oleh keempat karakteristik responden.

Hasil analisis regresi memperlihatkan bahwa hubungan positif antara tingkat partisipasi masyarakat dalam kegiatan mitigasi perubahan iklim (Y) terjadi dengan faktor tingkat pendidikan (X2) dan penyuluhan (X4), sedangkan umur (X1) dan pendapatan (X3) memiliki hubungan negatif.

Hasil analisis regresi untuk faktor pendidikan (X2) dengan tingkat partisipasi dalam kegiatan mitigasi perubahan iklim adalah positif $(b=2,007)$, hal ini berarti semakin tinggi tingkat pendidikan, maka tingkat partisipasi mereka dalam kegiatan mitigasi perubahan iklim akan semakin meningkat. Hal ini dikarenakan tinggi rendahnya pendidikan seseorang memepengaruhi dalam pelaksanaan suatu kegiatan. Mereka yang berpendidikan tinggi relatif lebih cepat dalam melakukan anjuran pemerintah/penyuluh. Tingkat pendidikan 
yang rendah pada umumnya kurang menyenangi inovasi sehingga sikap mental untuk menambah pengetahuan khususnya ilmu pertanian kurang. Pendidikan dianggap dapat mempengaruhi sikap seseorang dalam memutuskan sesuatu yang terbaik bagi dirinya untuk ikut berpartisipasi atau tidak dalam program-program pembangunan(Jaya et a,l, 2016).

Sedangkan hasil analisis untuk faktor umur (X1) dan pendapatan (X3) memiliki hubungan negatif. Untuk umur (X1) dengan tingkat partisipasi dalam kegiatan mitigasi perubahan iklim adalah negatif $(=0.049)$.

Hasil penelitian ini mengindikasikan bahwa semakin tinggi umur seseorang maka tingkat partisipasi mereka dalam kegiatan mitigasi perubahan iklim akan semakin menurun. Seseorang dalam usia produktif $30-50$ tahun akan mempunyai tanggung jawab yang lebih besar dalam menghidupi dirinya dan keluarganya. Pada kisaran umur tersebut, petani mencapai kematangan dalam bertani karena sudah ditekuni sejak usia muda, dan termasuk umur produktif. Umur tenaga kerja cukup menentukan keberhasilan dalam melakukan suatu pekerjaan, baik sifat fisik maupun non fisik. Pada umumnya, tenaga kerja yang berumur tua mempunyai tenaga fisik yang lemah dan terbatas, sebaliknya tenaga kerja yang berumur muda mempunyai kemampuan fisik yang kuat (Amron, 2009).
Hasil perhitungan koefisien korelasi untuk tingkat penyuluhan (X4) dengan tingkat partisipasi memperlihatkan bahwa hasil positif ( $\mathrm{t}=1,410)$, hal ini menunjukan penyuluhan bernilai positif terhadap partisipasi masyarakat dalam melaksanakan kegiatan mitigasi. Penyuluhan sebagai proses komunikasi pembangunan, dimana penyuluhan tidak sekedar upaya untuk menyampaikan pesanpesan pembangunan, tetapi yang lebih penting dari itu adalah untuk menumbuh kembangkan partisipasi masyarakat dalam pembangunan (Mardikanto, 1993). Melalui pelaksanaan penelitian ilmiah diharapkan dapat menyempurnakan pelaksanaan suatu jenis kegiatan serta pertukaran informasi dan pengalaman dalam rangka meningkatkan pelaksanaan kegiatan mitigasi. Oleh karena itu dalam pelaksanaan penyuluhan diharapkan dapat berlangsung lebih inovativ dan efektif, sehingga tujuan dari pelaksanaan kegiatan dapat terlaksana dengan baik dan tepat sasaran.

Hasil perhitungan koefisien korelasi untuk tingkat pendapatan (X3) dengan tingkat partisipasi memperlihatkan hasil negatif $(\mathrm{t}=0,608)$. Hal ini memperlihatkan bahwa semakin rendah pendapatan seseorang maka tingkat partisipasi mereka akan semakin meningkat, sebaliknya apabila pendapatan mereka meningkat maka partisipasi mereka dalam kegiatan kelompok akan menurun. Hal 
ini memperlihatkan bahwa mayoritas masyarakat berpartisipasi dalam kegiatan mitigasi perubahan ikilm, hal ini dikarenakan kegiatan mitigasi ini merupakan kegiatan sehari-hari yang dilaksanakan oleh masyarakat dan merupakan bagian dari pekerjaan mereka yang mayoritas adalah petani. Dengan semakin rendah tingkat pendapatan masayrakat akat semakin berpartisipasi dalam kegiatan mitigasi karena dapat memberikan atau meningkatkan pendapatan keluarga mereka.

3.3 Analisis Hubungan Sosial Ekonomi Masyarakat Terhadap Tingkat Partisipasi Masyarakat Pada Kegiatan mitgasi Perubahan Iklim

Analisis regresi linear berganda untuk tingkat partisipasi masyarakat dalam kegiatan kelompok masyarakat dan dukungan keberlanjutan diperoleh model persamaan sebagai berikut $\mathrm{Y}=36,242-0,013 \mathrm{X}_{1}+0,887 \mathrm{X}_{2}$ $+0,041 X_{3}+0,571 X_{4}$. Hasil perhitungan analisis korelasi diketahui bahwa korelasi antara variabel $X_{1}$ sampai dengan $X_{4}$ dengan variabel $\mathrm{Y}$ adalah sebesar 36,242 ,hal ini menjelaskan bahwa tingkat partisipasi masyarakat dalam kegiatan kelompok masyarakat dan dukungan keberlanjutan dipengaruhi oleh keempat karakteristik responden.

Hasil analisis regresi memperlihatkan bahwa hubungan positif antara tingkat partisipasi masyarakat dalam kegiatan kelompok masyarakat dan dukungan keberlanjutan (Y) terjadi dengan faktor tingkat pendidikan (X2) dan penyuluhan (X4), sedangan umur(X1,) pendapatan (X3) memiliki hubungan negative.

Hasil analisis regresi untuk faktor pendidikan (X2) dengan tingkat partisipasi dalam kegiatan kelompok masyarakat dan dukungan keberlanjutan adalah positif $(\mathrm{t}=$ 0,097), hal ini berarti semakin bertambah tinggi tingkat pendidikan, maka tingkat partisipasi mereka dalam kelompok masyarakat dan dukungan keberlanjutan akan semakin meningkat. Hal ini dikarenakan tinggi rendahnya pendidikan seseorang memepengaruhi dalam pelaksanaan suatu kegiatan. Mereka yang berpendidikan tinggi relatif lebih cepat dalam melakukan anjuran pemerintah/penyuluh. Tingkat pendidikan yang rendah pada umumnya kurang menyenangi inovasi sehingga sikap mental untuk menambah pengetahuan khususnya ilmu pertanian kurang. Pendidikan dianggap dapat mempengaruhi sikap seseorang dalam memutuskan sesuatu yang terbaik bagi dirinya untuk ikut berpartisipasi atau tidak dalam program-program pembangunan (Jaya et a,l, 2016).

Sedangkan hasil analisis untuk faktor umur (X1) dan pendapatan (X3) memiliki hubungan negatif. Untuk umur (X1) dengan tingkat partisipasi dalam kegiatan kelompok masyarakat dan dukungan keberlanjutan adalah 
negatif $(t=-0, .292)$ dan $(t=0,061)$. Hasil ditingkatkan lagi kreatifitas mayarakat dalam penelitian ini mengindikasikan bahwa semakin tinggi umur seseorang maka tingkat partisipasi mereka dalam kegiatan kelompok masyarakat dan dukungan keberlanjutan akan semakin menurun. Seseorang dalam usia produktif $30-50$ tahun akan mempunyai tanggung jawab yang lebih besar dalam menghidupi dirinya dan keluarganya dibandingkan mereka yang berusia dibawah 30 tahun maupun di atas 50 tahun. Pada kisaran umur tersebut, petani mencapai kematangan dalam bertani karena sudah ditekuni sejak usia muda, dan termasuk umur produktif. Umur tenaga kerja cukup menentukan keberhasilan dalam melakukan suatu pekerjaan, baik sifatnya fisik maupun non fisik. Pada umumnya, tenaga kerja yang berumur tua mempunyai tenaga fisik yang lemah dan terbatas, sebaliknya tenaga kerja yang berumur muda mempunyai kemampuan fisik yang kuat (Amron, 2009).

Hasil perhitungan koefisien korelasi untuk tingkat penyuluhan (X4) dengan tingkat partisipasi memperlihatkan bahwa hasil negatif $(\mathrm{t}=-0,061)$, hal ini menunjukan penyuluhan bernilai negatif terhadap partisipasi masyarakat dalam melaksanakan kegiatan kelompok masyarakat dan dukungan keberlanjutan maka dapat disarankan, agar penyuluhan tentang kegiatan perubahan ikilm tidak sekedar hanya menyampaikan pesan, tetapi lebih lebih pelaksanaan kegiatan, serta dilaksanakannya pelatihan-pelatihan bagi seluruh masyarakat. Penyuluhan sebagai proses komunikasi pembangunan, penyuluhan tidak sekadar upaya untuk menyampaikan pesan-pesan pembangunan, tetapi yang lebih penting dari itu adalah untuk menumbuh kembangkan partisipasi masyarakat dalam pembangunan (Mardikanto, 1993).

Hasil perhitungan koefisien korelasi untuk tingkat pendapatan (X2) dengan tingkat partisipasi memperlihatkan hasil negatif $(\mathrm{t}=$ 0,061). Hal ini memperlihatkan bahwa semakin rendah pendapatan seseorang maka tingkat partisipasi mereka akan semakin meningkat, sebaliknya apabila pendapatan mereka meningkat maka partisipasi mereka dalam kegiatan kelompok masyarakat dan dukungan keberlanjutan akan menurun. Hal ini memperlihatkan bahwa mayoritas masyarakat berpartisipasi dalam kegiatan perubahan ikilm, hal ini dikarenakan kegiatan ini merupakan kegiatan sehari-hari yang dilaksanakan oleh masyarakat dan juga merupakan bagian dari pekerjaaan mereka yang mayoritas adalah petani. Masyarakat berharap melalui keterlibatan mereka dalam kegiatan tersebut dapat memberikan atau meningkatkan pendapatan keluarga mereka. Hal inilah yang membuat hasil penelitian ini berbeda dengan 
hasil penelitian pada umumnya, dimana jika penghasilan seseorang rendah maka tingkat partisipasi mereka akan rendah karena sebagian besar waktu mereka habiskan untuk memenuhi kebutuhan hidup mereka sehari-hari.

Berdasarkan hasil perhitungan koefisien korelasi tingkat partisipasi masyarakat pada kegiatan adaptasi perubahan iklim, mitigasi perubahan iklim, kelompok masyarakat dan dukungan keberlanjutan pada ProKlim Desa Poleonro memperlihatkan, bahwa tingkat pendidikan masyarakat bernilai positif terhadap partisipasi masyarakat dalam melaksankan kegiatan program Kampung iklim. Sedangkan faktor umur, banyaknya penyuluhan dan tingkat pendapatan bernilai negatif.

Faktor sosial ekonomi masyarakat Desa Poleonro mempengaruhi tingkat partisipasi masyarakat dalam melaksanakan program Kampung iklim. Kegiatan program Kampung iklim yang dilaksanakan di Desa Poleonro merupakan bagian dari aksi lokal yang dapat meningkatkan pemahaman mengenai perubahan iklim dan dampak yang ditimbulkannya sehingga seluruh masyarakat terdorong untuk melaksanakan aksi nyata yang dapat memperkuat ketahanan masyarakat menghadapi perubahan iklim serta memberikan kontribusi terhadap upaya pengurangan emisi GRK.

\section{KESIMPULAN}

Berdasarkan hasil penelitianmaka diperoleh kesimpulan sebagai berikut:

1. Efektivitas Pelaksanaan Program Kampung Iklim (ProKlim) di Desa Poleonro termasuk pada kategori cukup efektif, sesuai dengan komponen kegiatan program Kampung iklim telah melakukan kegiatan adaptasi perubahan ikilm dengan persentase sebesar $70,12 \%$, kegiatan mitigasi perubahan iklim dengan persentase sebesar $60,06 \%$ dan kegiatan kelompok masyarakat dan dukungan keberlanjutan dengan persentase sebesar $72,77 \%$.

2. Tingkat partisipasi masyarakat dalam pelaksanaan kegiatan Program Kampung Iklim di Desa Poleonro untuk adaptasi perubahan iklim, kegiatan mitigas perubahan iklim, kegiatan kelompok masyarakat dan dukungan keberlanjutan tingkat partisipasinya tinggi

3. Tingkat pendidikan dan penyuluhan memiliki hubungan positif terhadap kegiatan Proklim sedangkan variable umur dan tingkat pendapatan memiliki hubungan negatif terhadap tingkat partisipasi msyarakat pada kegiatan ProKlim terhadap tingkat partisipasi msyarakat pada kegiatan ProKlim. 


\section{UCAPAN TERIMA KASIH}

Kepada Kepala Desa Poleonro Kecamatan Lamuru Kabupaten Bone, para pembimbing dan penguji serta keluarga tercinta serta teman teman yang tidak bisa disebutkan satu persatu atas bantuan dan suportnya dalam penelitian ini.

\section{DAFTAR PUSTAKA}

Ahmad Ilham Puspito, 2016. Implementasi Program Kampung Iklim Di Kelurahan Plalangan Kecamatan Gunungpati Kota Semarang. Universitas Negeri Semarang

Balai PPIKHL Wilayah Sulawsei, 2019. Laporan Verifikasi Program Kampung Iklim. Makassar.

Balai PPIKHL Wilayah Sulawsei, 2019. Rencana Kerja (Renja). Makassar

Bappenas. 2014. Rencana Pembangunan Jangka Menenegah Nasional Tahun 2014 - 2019. Jakarta

Daryanto (Anis Sudijono, 2009) Indonesia Climate Change Trusth Fund (ICCFT), 2015. Laporan Akhir Tahun 2015.Jakarta

Faedlulloh, dodi dkk.2019. Program Kampung Iklim (Proklim) berbasis pemberdayaan masyarakat.

Fitriyya, M. (2012), Pengaruh Pendidikan Kesehatan Tentang Inisiasi Menyusu Dini Melalui Kombinasi Metode CeramahTanya Jawab-Leaflet Terhadap Pengetahuan dan Sikap Ibu Hamil di RB An-Nisa Surakarta, Tesis., Universitas Sebelas Maret, Surakarta.

Handayaningrat, Soewarno. 2006. Pengantar Studi Ilmu Administrasi dan Manajemen. Jakarta
Indonesia Climate Change Trusth Fund (ICCFT), 2016. 18 Aksi ICCTF Program 2016. Jakarta.

Kementerian Lingkungan Hidup dan Kehutanan(KLHK),2016. Perubahan Iklim, Perjanjian Paris dan Nationally Determined Contribution. Edisi 1. Direktorat Jenderal Pengendalian Perubahan Iklim Kementerian Lingkungan Hidup dan Kehutanan.Jakarta

Kementerian Lingkungan Hidup dan Kehutanann(KLHK),2017. Road MAP Program Kampung Iklim (PROKLIM).Gerakan Nasional Pengendalian Perubahan Iklim Berbasis Masyarakat. Direktorat Jenderal Pengendalian Perubahan Iklim Kementerian Lingkungan Hidup dan Kehutanan.Jakarta

Nurhidayat, M.2017. Tesis Tingkat Partisipasipasi Masyarakat dalam pelaksanaan Program Model Desa KOnservasi di Taman Nasional Bantimurung Bulusaraung (studi kasus Desa Labuaja Kecamatan Ceenrana Kabupaten Maros)

Peraturan Menteri Lingkungan Hidup No.19 tahun 2012 tentang Program Kampung Iklim. Jakarta

Peraturan Menteri Negara Lingkungan dan Kehutanan Hidup Republik Indonesia Nomor P.84/MENLHKSETJEN/KUM.1/11/2016 Tentang Program Kampung Iklim. Jakarta: Kementerian Lingkungan Hidup.

Peraturan Dirjen Pengendalian Perubahan Iklim No.1 tahun 2017 tentang Pedoman Pelaksanaan Program Kampung Iklim.Jakarta.

Renaldy,Reza 2017. Proses Community Development pada Program Kampung Iklim di Desa Cupang Kecamatan Gempol Kabupaten Cirebon (Studi Kasus 
Program Bank Sampah dalam Program Kampung Iklim).

Ria Angreani, 2017. Tesis Partisipasi Masyarakat Dalam Pelaksanaan Program Gerakan Membangun Desa Sai Bumi Ruwa Jurai (Gerbanbg Desa Saburai). program Pascasarjana Magister Ilmu Pemerintahan Fakultas Ilmu Sosial dan Ilmu Politik Universitas Lampung.

Rifyanti, Rieke, 2018. Evaluasi Program Kmapung Iklim dalam mengurangi resiko dampak perubahan iklim Desa Nglegi Kecamatan Patuk Kabupaten Gunungkidul.

Sahidu, Arifudin, 2008, Partisipasi Masyarakat Tani Pengguna Lahan Sawah dalam Pembangunan Pertanian di Daerah Lombok, Nusa Tenggara Barat. Disertasi. Pascasarjana, IP

Sedarmayanti, 2006. Manajemen Sumber Daya Manusia dan Profuktivitas Kerja.Bandung
Temuan Ilmiah Perubahan Iklim dan Implikasinya pada Kontribusi Nasional Indonesia di Tingkat Global 2014. Laporan IPCC ke-5 dan Dampaknya Pada Indonesia. Institute for Essential Services Reform (IESR)

Wyzer, Yolanda Vemmy, 2017, Tesis Kajian Pelaksanaan Program Kampung Iklim di Kampung Margorukun Distrik Oransbari Kabupaten Manokwari Provinsi Papua Barat. Program Pascasarjana Program Studi Ilmu Lingkungan Universitas Negeri Papua.

Wahab, Akbar Ali, 2015, Tesis Strategi Pengembangan Program Kampung Iklim (Proklim) di Desa Mangempang Kecamatan Bungaya Kabupaten Gowa Provinsi Sulawesi Selatan. Program Pascasarjana Universitas Hasanuddin Program Studi Pengelolaan Lingkungan Hidup. 